\title{
Epidural analgesia for labour in a patient with Ebstein's anomaly
}

Ebstein's anomaly is an uncommon congenital cardiac defect which is associated with cyanosis and arrhythmias. There have been very few previous reported cases of successful outcome in pregnancy in women with this disorder. We describe the successful analgesic management of an obstetric patient who had been known to have Ebstein's anomaly since childhood. Her first pregnancy was uneventful and analgesia during labour was provided by an epidural. During her second pregnancy she presented to our hospital as her condition had deteriorated. Symptomatic control was achieved with digoxin. Despite this, several episodes of hospitalization were needed pre-partum for rest and oxygen therapy. After the onset of spontaneous labour, analgesia was managed by an epidural using bupivacaine. Invasive monitoring was not deemed appropriate due to increased risk and questionable usefulness. Vaginal delivery was managed with elective lift-out forceps to minimize the stress of pushing. When reviewed two months post-partum she still required digoxin although her symptoms had improved considerably. The successful management of Ebstein's anomaly in pregnancy should include team management from early in pregnancy.

La maladie d'Ebstein évoque une anomalie congénitale associée $\grave{a}$ de la cyanose et à des arythmies. On connaît très peu de cas d'évolution favorable de la grossesse chez les parturientes atteintes de cette anomalie. Nous décrivons la gestion analgésique heureuse d'une parturiente connue comme porteuse de la maladie d'Ebstein depuis son enfance. Sa première grossesse sétait déroulée sans complications et elle avait bénéficié pendant le travail d'une analgésie épidurale. $A$ sa deuxième grossesse, elle se présente à notre hôpital en mauvais état. Ses symptômes

\section{Key words}

ANAESTHESIA: obstetrical;

ANAESTHETIC TECHNIQUES: epidural;

COMPLICATIONS: Ebstein's anomaly.

From The Department of Anaesthetics, The Northem General Hospital, Sheffield, S5 7AU, U.K.

Address correspondence to: Dr. E.R. Groves, Lecturer in Anaesthesia, The Department of Surgical and Anaesthetic Sciences, University of Sheffield, K Floor, The Royal Hallamshire Hospital, Sheffield, S10 2JF, U.K.

Accepted for publication 17th September 1994. sont traités à la digoxine. Malgré cela, elle doit être hospitalisée à plusieurs reprises avant l'accouchement pour repos et oxygénothérapie. Après un début spontané de travail, on institue une analgésie épidurale à la bupivacaîne. Parce quil augmente le risque et quil est d'utilité douteuse, le monitorage invasif n'est pas jugé nécessaire. L'extraction vaginale est réalisée au forceps pour éliminer le stresss de la poussée. Lorsqu'elle consulte deux mois après l'accouchement, son état nécessite toujours de la digoxine bien quelle cliniquement en meilleur état. Lévolution favorable de la grossesse chez une porteuse de la maladie d'Ebstein nécessite une prise en charge multidisciplinaire et précoce.

Ebstein's anomaly is a rare downward displacement of the tricuspid valve such that the right ventricle has a distal effective portion and an atrialised proximal portion. The anomaly is frequently associated with an atrial septal defect and the patients are subject to paroxysmal arrhythmias which may be supraventricular or ventricular. The Wolff-Parkinson-White syndrome occurs in up to $20 \%$ of patients. ' Clinically there is a wide spectrum of severity with an average life expectancy of 25 to $30 \mathrm{yr}$. Patients range from those who are asymptomatic to those who are cyanosed with a right-to-left shunt and high pulmonary vascular resistance. ${ }^{2}$ Congestive heart failure and sudden collapse are the most common causes of death. The risk of death from embolism during pregnancy is increased because of the higher incidence of thromboembolic disease. ${ }^{3}$ Pregnancy also increases the risk of congestive cardiac failure. The incidence of Ebstein's anomaly in the general population has been estimated as 1 in 110,000 . There is no sex difference.

\section{Case report}

A 24-yr-old woman with Ebstein's anomaly diagnosed during childhood presented at another hospital for obstetric care during the pregnancy of her first child. Apart from occasional runs of supraventricular tachycardia she was asymptomatic and was receiving no treatment. On examination she had pansystolic and mid-diastolic murmurs with a widely split second sound. An ECG showed sinus rhythm with right bundle branch block. A previous chest $x$-ray had shown a large right atrium with the heart 
size at the upper limit of normal. An echocardiogram carried out seven years previously had failed to show an atrial septal defect but confirmed the downward displacement of the tricuspid valve with a large right atrium and a normal pulmonary valve and artery.

When she went into labour she had an early elective epidural sited at $\mathrm{L}_{3 / 4}$ using bupivacaine $0.25 \%$ for analgesia. An hour after it was commenced she suddenly became centrally cyanosed and breathless. This resolved on turning her into the left lateral position and giving her $8 \mathrm{~L} \cdot \mathrm{min}^{-1}$ oxygen via a face mask. Over the next eight hours she remained cardiovascularly stable and eventually had an elective forceps delivery of a healthy child. In total, $52 \mathrm{ml}$ bupivacaine had been administered. Continuous analgesia had been supplied by intermittent topups.

During the next three years her symptoms increased with palpitations, syncopal attacks, shortness of breath on exertion and episodes of ankle swelling. These were treated with sotalol $160 \mathrm{mg}$ bd. At the age of 27 she became pregnant for the second time and was referred to our hospital where a multidisciplinary team approach to her pregnancy was instituted. Her treatment was changed to digoxin $125 \mathrm{mg}$ od as our experience of sotalol in pregnancy was limited. During this pregnancy she required several admissions for rest and oxygen therapy as she developed increasing tiredness and mild cyanosis. She was allowed to go into spontaneous labour at 39 wk. At that time her arterial oxygen saturation was between 82 and $86 \%$ breathing room air and 90 to $93 \%$ with $4 \mathrm{~L} \cdot \min ^{-1}$ oxygen via a face mask. Her admission blood pressure was $110 / 70 \mathrm{mmHg}$ and she was in sinus rhythm with a rate of $80 \mathrm{bpm}$. Her chest was clear with no signs of heart failure. The heart sounds were as before. Laboratory investigations showed a haemoglobin of $\mathbf{1 3 . 5}$ $\mathrm{g} \cdot \mathrm{dl}^{-1}$ and normal coagulation and electrolytes. Following consultation between cardiologists, anaesthetists and obstetricians she again had an elective epidural sited at $\mathrm{L}_{3 / 4}$. During her six hours in labour a total of $18 \mathrm{ml}$ bupivacaine $0.25 \%$ was administered (intermittent topups of $6 \mathrm{ml}$ being the method chosen to ensure that the level of analgesia did not rise too high) and eventually $10 \mathrm{ml}$ bupivacaine $0.5 \%$ (given slowly in aliquots of 2.5 $\mathrm{ml}$ ) were given to allow an elective forceps delivery of a healthy child. Again she remained cardiovascularly stable with her blood pressure during labour ranging between $112 / 59$ and $143 / 81 \mathrm{mmHg}$. Sinus rhythm was maintained throughout.

In both labours syntocinon im was given to aid the third stage and prophylactic antibiotics were administered. When reviewed two months later she still required digoxin although her symptoms had improved considerably since delivery.

\section{Discussion}

The hazards of pregnancy in Ebstein's anomaly include a deterioration in right ventricular function due to increased blood volume and cardiac output, increased right-to-left shunting and cyanosis (if an atrial septal defect is present) due to decreased systemic vascular resistance. ${ }^{4}$ The raised concentrations of circulating catecholamines in pregnancy will exacerbate any predisposition to arrhythmias, and major arrhythmias may occur, particularly if there is maternal hypoxaemia or stress. The fetus, therefore, may be hypoxic and at increased risk from intrauterine growth restriction and death. If preeclampsia and hypertension occurs, there is a marked rise in systemic vascular resistance and a low wedge pressure and cardiac output. Because of these changes, patients with severe cardiac disease may develop congestive heart failure if pre-eclampsia develops. ${ }^{5}$ Women with Ebstein's anomaly who reach childbearing age can usually be advised that pregnancy will be well tolerated and fetal outcome good. ' The presence of arrhythmias or cyanosis in the mother (both of which occurred in our patient) are associated with increased maternal and fetal risk and are indications for closer maternal and fetal observation during pregnancy and delivery.

The basic principles of anaesthetic management of a patient with cardiac disease are to maintain both afterload and preload and to maintain sinus rhythm. Increased right-to-left shunting will occur if there is a decrease in peripheral vascular resistance, an increase in pulmonary vascular resistance or an increase in intrathoracic pressure.

The advantages of siting an epidural in cardiac patients include effective analgesia which can be extended to provide anaesthesia for Caesarean section if necessary. It also minimizes the intravascular volume shifts ${ }^{4}$ which might otherwise be caused by autotransfusion during uterine contraction, sudden blood loss and relief of inferior vena caval obstruction. The tachycardia and tachypnoea associated with inadequate pain relief can be avoided. However, epidural anaesthesia in these patients may prompt right-to-left shunting and hypotension due to decreased peripheral vascular resistance. Hypotension may be avoided by careful positioning of the patient during labour, the use of anti-embolism stockings to reduce venous pooling and by using low-dose local anaesthetics titrated to effect. The addition of epidural opioids may be helpful in decreasing the amount of local anaesthetic required to produce adequate analgesia. Over-enthusiastic volume therapy may result in fluid overload and right ventricular failure. Ephedrine is a sympathomimetic amine that stimulates both $\alpha$ - and $\beta$-adrenergic receptors. Therefore, it increases heart rate as well as increasing both systolic and diastolic pressure. However, in instances in which 
a vasopressor becomes necessary, it may still be the most useful agent. It does not seem to effect pulmonary vascular resistance and also, unlike typical $\alpha$-adrenergic agonists such as methoxamine and phenylephrine, it does not produce extensive uterine vasoconstriction. Intrathecal anaesthesia is contraindicated in patients with rightto-left intracardiac shunts as profound hypotension may occur because of the rapid loss of sympathetic tone of the lower body. This would severely exacerbate maternal hypoxaemia. ${ }^{5}$ Intravenous and intrathecal narcotics, however, may be useful provided adequate analgesia is provided without respiratory depression.

When performing an epidural in a patient with an intracardiac septal defect, the loss of resistance to saline should be used as accidental intravenous injection of air (with the risk of a paradoxical embolus) can occur with the loss of resistance to air technique. ${ }^{6}$ Air bubbles in venous access lines should also be meticulously avoided.

Our patient presented in labour with cyanosis, possibly due to right-to-left shunt (although an ASD had not been found on her echocardiogram), pulmonary oedema or pulmonary embolism. We chose to treat her as noninvasively as possible as the insertion of a central line or pulmonary artery catheter would have increased the likelihood of arrythmias, paradoxical emboli leading to stroke, and bacterial endocarditis. ${ }^{2,5}$ Therefore, we monitored her continuously using a pulse oximeter, ECG and non-invasive blood pressure measurements. In view of the potential problems of labour in patients with cardiac disease it would seem wise to administer oxygen to all such patients whether or not they are cyanosed as it may decrease the resistance of the pulmonary vasculature. In patients with severe cardiac disease and pre-eclampsia or major obstetric haemorrhage an epidural anaesthetic may cause profound hypotension that is difficult to treat. In these patients more invasive cardiac monitoring may be advisable despite the risks. General anaesthesia may then be the method of choice for the operative delivery.

Maternal mortality is increased after Caesarean births in women with normal cardiovascular systems. Women with marginal cardiac reserve face added risks associated with postoperative fluid shifts, post-surgical pain and a higher incidence of throboembolism after operative delivery. ${ }^{8}$ There have been several previous reports of Caesarean section with epidural anaesthesia in patients with Ebstein's anomaly. ${ }^{2,4}$ Problems of general anaesthesia in patients with Ebstein's anomaly include an increased intrathoracic pressure when positive pressure ventilation is used. This will increase right-to-left shunting. A prolonged induction time in patients with an intracardiac shunt will also occur, increasing the risk of aspiration of gastric contents. A rapid sequence induction, used in all Caesarean section patients, and its haemodynamic consequences will be particularly damaging in patients with cardiac lesions. The use of a high-dose opioid anaesthetic may, however, avoid the sudden haemodynamic changes associated with induction of anaesthesia and tracheal intubation. If general anaesthesia is chosen, hypotension is usually avoided and fluid balance is easier to control. Oxygenation may be controlled by increasing the inspired oxygen content and by adding positive end expiratory pressure if pulmonary congestion occurs.

Synthetic oxytocin has marked but transient vasodilating effects when given in large doses and it should be given with caution in patients with cardiac disease. In our patient, syntocinon $10 \mathrm{iu}$ im caused no appreciable haemodynamic effect but was effective in aiding the third stage and preventing post-partum haemorrhage. Prostaglandin $F_{2 \alpha}$ may be a useful alternative. Ergometrine should be avoided in these patients because of its adverse effects on the pulmonary vasculature. ${ }^{2}$ Patients should receive antibiotics as prophylaxis against bacterial endocarditis.

Women with this condition should be considered high risk and cared for in tertiary centres by a multidisciplinary team including obstetricians, cardiologists and obstetric anaesthetists in pregnancy and during delivery. ${ }^{7}$

\section{References}

1 Donnelly JE, Brown JM, Radford DJ. Pregnancy outcome and Ebstein's anomaly. Br Heart J 1991; 66: 368-71.

2 Linter SPK, Clarke K. Caesarean section under extradural analgesia in a patient with Ebstein's anomaly. $\mathrm{Br} \mathrm{J}$ Anaesth 1984; 56: 203-5.

3 Litller WA. Successful pregnancy in a patient with Ebstein's anomaly. Br Heart J 1970; 32: 711-3.

4 Waickman LA, Skorton DJ, Varner MW, Ehmke DA, Goplerud $C P$. Ebstein's anomaly and pregnancy. Am J Cardiol 1984; 53: 357-8.

5 Halpern S, Gidwaney A, Gates B. Anaesthesia for Caesarean section in a pre-eclamptic patient with Ebstein's anomaly. Can Anaesth Soc J 1985; 32: 244-7.

6 Rowbottom SJ, Gin T, Cheung LP. General anaesthesia for Caesarean section in a patient with uncorrected complex cyanotic heart disease. Anaesth Intensive Care 1994; 22: 74-8.

7 Daliento L, Zevallos JC, Scognamiglio $R$, et al. Ebstein's anomaly and pregnancy. G Ital Cardiol 1987; 17: 374-8.

8 Smedstad KG, Cramb R, Morison DH. Pulmonary hypertension and pregnancy: a series of eight cases. Can $\mathbf{J}$ Anaesth $1994 ;$ 41:6 502-12. 